\title{
Spatial variability of the yield and physical properties of orange (Citros sinensis [L.] Osbeck cv. Monte Parnaso) fruits
}

\author{
Rafaela Fernandes Nicolau ${ }^{1 *}$, Erivelto Mercante ${ }^{1}$, Marcio Furlan Maggi ${ }^{1}$, Eduardo Godoy de Souza ${ }^{1}$, \\ Eloi Gasparin ${ }^{2}$, Bruno Bonemberger da Silva ${ }^{1}$
}

${ }^{1}$ UNIOESTE - Universidade Estadual do Oeste do Paraná, Campus Cascavel, PR, Post-Graduate Program in Agricultural Engineering, Rua Universitária, 2069 - JD. Universitário, 85819-110, Paraná, Brazil

${ }^{2}$ UFOPA - Universidade Federal do Oeste do Pará, Campus Santarém, PA, Institute of Biodiversity and Forests, Unidade Tapajós, Rua Vera Paz, s/n - Salé, 68035-110, Pará, Brazil

\section{*Corresponding author: rafa.nicolau@hotmail.com}

\begin{abstract}
Precision agriculture (PA) is used as a tool in the citrus industry and aims to increase production reduce costs and search for answers to explain the spatial variability of yield. The aim of this study was to model the spatial variability of yield and physical properties of fruits of orange trees in relation to the geographic quadrant where the fruits are on the trees. The experiment was carried out in a 1 ha commercial orchard of orange trees cv. Monte Parnaso. A GPS receiver and a total station were used to georeference the experimental area and the position of each sampled tree in the area, as well as the location of the geographic quadrant where the fruits sampled were on the trees. Twelve fruits were collected from each of the 13 sampled trees, resulting 39 fruits per quadrant, totalling 156 fruits each crop-year (2011 and 2012). Yield was estimated after the harvest (kg.quadrant ${ }^{-1}$ ). Physical analyses were performed for each fruit, measuring the following physical properties: equatorial diameter, total mass and juice yield. We conducted analysis of descriptive statistics and spatial variability in the data through techniques related to geostatistics. The results showed the highest spatial variability between the quarters for the juice yield and yield, and the verified juice yield was within the acceptable standard by regulatory bodies.
\end{abstract}

Keywords: orange fruits, spatial dependence, geographic quadrants, variability, physical properties.

Abbreviations: PA_precision agriculture; TA_total titratable acidity; CV_coefficient of variation; ED_equatorial diameter; HLB_ huanglongbing; DSD_degree of spatial dependence; TM_total mass; NE_northeast; NW_northwest; JY_juice yield; SE_southeast; SW_southwest; TSS_total soluble solids.

\section{Introduction}

The orange is the most produced and commercialised fruit in the world; however, the main problem for producers is to manage the spatial variability, since there are several factors that may be involved related to production, such as, pest infestation outbreaks and diseases, soil type, soil compaction and management (Molin, 2010), soil-relief relationship and water movement in the soil (Siqueira et al., 2010). Understanding the spatial variability of yield and physical properties of the soil, as well as the study of the temporal variability when properly available to farmers who adopt precision agriculture, can improve the management options and enable modern agriculture that is economically competitive and environmentally sustainable (Molin \& Rabelo, 2011; Bernardi et al., 2014).

The growth potential of agribusiness and the emergence of new technologies, innovation and research have promoted the dynamism of the citrus sector. The use of precision agriculture in the citrus industry aims to increase production, reduce costs and search for answers to explain the spatial variability of yield. According to this concept, Molin et al. (2012) characterised the spatial variability of fruit yield, soil fertility and occurrence of plant failures caused by declining citrus and rust or huanglongbing (HLB) and concluded that the variability found in the studied parameters demonstrated the importance of nutritional and phytosanitary localised management as tools to ensure efficiency in the fruit production.

Siqueira et al. (2010) used the landforms to predict the spatial variability of soil and orange attributes. The orange properties evaluated were total soluble solids (TSS), total titratable acidity (TA), TSS/TA ratio, production, juice yield (JY) and fruit size, performed during three months (July, August and September). The results showed that the spatial and temporal variability of soil and orange attributes are influenced by the relief, especially the temporal variability of the orange attributes that influence the ripening gradients.

Cruz et al. (2010) evaluated whether the exposure of plants and tangerine fruits to heatstroke influence the physicochemical characteristics. They concluded that fruits located in the western quadrant of the tree canopy presented higher TSS values and greater size, and smaller acidity in relation to fruits positioned in the eastern quadrant. Lemos et al. (2012) evaluated the physicochemical characteristics of the sweet orange fruits [Citrus sinensis (L.) Osb] collected at different positions of the canopy: heights (basal, middle and apical), both sides (opposite sides of the canopy, between 
lines - east and west) and two positions (periphery and $30 \mathrm{~cm}$ inside the canopy). They concluded that the sampling point within the parameters required for a better quality of orange varied for the different positions in the canopy.

In this context, the aim of this study was to model the spatial variability of yield and physical properties of fruits of orange trees in relation to the geographic quadrant where the fruits are on the trees.

\section{Results and Discussion}

\section{Statistical Analysis}

Descriptive analyses of the physical properties and orange yield in relation to geographic quadrants were carried out for two years, 2011 and 2012 (Table 1). Considering the ideal standards for maturation of an orange fruit proposed by Azevêdo (2003) and CEAGESP (2011), the minimum JY is from 35 to $45 \%$; the average values collected were from 41.9 to $44.9 \%$ in 2011 and from 43.4 to $48.7 \%$ in 2012 , thereby determining that JY values are within acceptable standards. According to Koller (2006) the variety Monte Parnaso is not very productive, averaging $15 \mathrm{~kg}$.tree ${ }^{-1}$. The average yield found in the experiment was $16 \mathrm{~kg} \cdot \mathrm{tree}^{-1}$ for the year 2011 and $17 \mathrm{~kg}$.tree- ${ }^{1}$ for 2012.

Duarte et al. (2011), working with the Valencia orange, found JY values ranging from 53 to $56 \%$ and fruit weight ranging from 141 to $190 \mathrm{~g}$. Castro et al. (2013) evaluated JY, TSS and TSS/TA in some orange cultivars and found JY values within acceptable standards according to Azevedo (2003) and CEAGESP (2011), ranging from 36 to 57\%, which is similar values to those found in this paper. Santarosa et al. (2013), in a study to assess the variation of intensity and frequency of pruning, found TM values similar to those found in our experiment, $280 \mathrm{~g}$, especially in the control treatment $(224 \mathrm{~g})$.

\section{Geostatistical Analysis}

Table 2 shows an analysis of the spatial variability model with the parameters of the adjusted models to semivariograms. The pure nugget effect was found, the data do not present spatial dependence indicating that these attributes were not influenced by the spatial location of the fruit on the tree canopy, for year 2011 the attributes TM and yield in SW quadrant, JY in NW quadrant and ED in SE quadrant.

The spatial dependence radius considered in this study was $110 \mathrm{~m}$, which was the maximum distance. Therefore, the variables that did not show that the pure nugget effect can be considered as dependent variables for not having a longer range than the maximum distance consistently to reality.

For the degree of spatial dependence (DSD) for the variables studied, in 2011, it was classified as weak spatial dependence (nugget effect $\geq 75 \%$ ) ED in SW quadrant. In $2012 \mathrm{ED}$ and TM in SW quadrant was classified as strong spatial dependence (nugget effect $\leq 25 \%$ ) in $2011 \mathrm{TM}$ and JY in SE quadrant and in 2012 the yield in SW and NE quadrant. The other variables were classified as moderate spatial dependence (nugget effect between $25 \%$ and $75 \%$ ) according to Cambardella et al.'s (1994) classification.

In a similar study, Molin et al. (2012) also found a high range of values (688.20) and randomness $(69.00 \%)$ for yield, similar to those found in this study in the NW and SE quadrants in 2012. The other variables showed spatial dependence.
Working with Pêra-Rio cultivar in 2002 and 2003, Siqueira et al. (2010) evaluated the spatial dependence for the attributes TA, TSS/TA and JY, and the attributes presented strong and moderate spatial dependence, evidencing similar results compared to this work. Zucoloto et al. (2011) found spatial dependence for total weight and DSD was classified as moderate for this physical property for the Folha Murcha orange cultivar.

\section{Spatial Distribution}

The spatial variability surface map of the physical characteristics and orange yield in relation to geographic quadrants, in 2011, are shown in Figure 1. The lowest ED and TM values were observed in the NE quadrant. On the other hand, in the NW quadrant of the ED variable, smoothing points were observed, which occurred from the interpolation process, as well as the variable TM in the NE quadrant. For ED and JY variables in the SW quadrant, we observed a continuity of estimated values of the variables.

The highest values found for JY were observed primarily in the NW quadrant. The yield maps represent the spatial variability of the orchard, growth and yield of plants showing complete information about the orchard (Oliveira et al., 2009). Therefore, the predominance of values in yield maps was observed, as ranging from 14 to $17 \mathrm{~kg}_{\text {.quadrant }}{ }^{-1}$ in all quadrants studied.

Surface maps of the physical characteristics and orange yield in relation to geographical quadrants in 2012 are shown in Figure 2. For ED and JY attributes, it was observed that in the NE/SE and SE quadrants, respectively, small dots occurred related to smoothing in the interpolation process. It was observed in the TM attribute that the highest values were primarily in the SW quadrant. The highest values for yield were found in the NW and SE quadrants.

Cruz et al. (2010) found that the tangerine fruit Ponkan, located in the western quadrant of the canopy, presented higher weight values and juice yield than those located in the east quadrant. Detoni et al. (2009) observed that the fruits developed in the orientation in which there is a higher incidence of sun, presented higher weight values and a longitudinal diameter. In a similar study, Molin et al. (2012) characterised the orange tree yield in a commercial orchard and found the non-occurrence of spatial dependence and large spatial variability in the orchard, as was observed in this study.

\section{Materials and Methods}

\section{Characterisation of the area}

The experiment was carried out in a 1 ha commercial orchard of orange trees cv. Monte Parnaso (Citros sinensis [L.] Osbeck), implanted in August 2005, using the Poncirus trifoliata (L.) Raf. as rootstock, spaced 4x6 m between plants. The experimental area is located in Nova Laranjeiras, the midwest region of the state of Parana, with a total area of about $1 \mathrm{ha}$, and centre coordinates are $25^{\circ} 23^{\prime} 03^{\prime}$ 'S latitude and $52^{\circ} 34^{\prime} 27^{\prime \prime} \mathrm{W}$ longitude (Figure 3a). The region's soil is classified as red dystroferric latosol consisting of approximately $76 \%$ clay. The climate is classified as a humid subtropical climate (Cfa), according to Köppen classification, with infrequent frosts events. The average temperature is 22 ${ }^{\circ} \mathrm{C}$ with hot summers. For the sampling of oranges, 12 fruits were collected from each of the 13 sampled trees, resulting 39 fruits per quadrant, totalling 156 fruits each crop-year (2011 and 2012). 
Table 1. Statistical analysis of the yield and physical properties of orange fruits in 2011 and 2012 located in Nova Laranjeiras, Paraná.

\begin{tabular}{|c|c|c|c|c|c|c|c|}
\hline & & 2011 & & & 2012 & & \\
\hline Quadrants & Properties & Mean & Extent & $\mathrm{CV}(\%)$ & Mean & Extent & $\mathrm{CV}(\%)$ \\
\hline \multirow{4}{*}{ SW } & $\mathrm{ED}(\mathrm{mm})$ & 78.65 & 31.00 & 8.77 & 84.70 & 27.46 & 6.39 \\
\hline & $\mathrm{TM}(\mathrm{g})$ & 258.20 & 272.50 & 24.15 & 310.40 & 244.00 & 17.42 \\
\hline & $\mathrm{JY}(\%)$ & 43.38 & 27.70 & 14.73 & 43.38 & 27.70 & 14.73 \\
\hline & Yield(kg.quadrant $\left.^{-1}\right)$ & 15.52 & 11.80 & 24.72 & 19.95 & 22.03 & 32.84 \\
\hline \multirow{4}{*}{ NW } & $\mathrm{ED}(\mathrm{mm})$ & 79.95 & 32.89 & 9.70 & 84.42 & 18.02 & 5.30 \\
\hline & $\mathrm{TM}(\mathrm{g})$ & 264.20 & 302.30 & 27.14 & 312.60 & 232.40 & 18.63 \\
\hline & $\mathrm{JY}(\%)$ & 44.88 & 16.70 & 9.45 & 47.62 & 15.40 & 7.68 \\
\hline & Yield(kg.quadrant $\left.{ }^{-1}\right)$ & 14.02 & 19.15 & 36.32 & 16.15 & 14.17 & 26.86 \\
\hline \multirow{4}{*}{ SE } & $\mathrm{ED}(\mathrm{mm})$ & 79.27 & 23.43 & 7.11 & 82.12 & 21.99 & 5.86 \\
\hline & $\mathrm{TM}(\mathrm{g})$ & 260.00 & 226.60 & 20.60 & 322.90 & 232.80 & 21.13 \\
\hline & $\mathrm{JY}(\%)$ & 41.97 & 14.70 & 7.99 & 48.69 & 13.51 & 6.36 \\
\hline & Yield(kg.quadrant $\left.^{-1}\right)$ & 17.64 & 12.36 & 21.12 & 13.09 & 11.94 & 28.94 \\
\hline \multirow{4}{*}{ NE } & $\mathrm{ED}(\mathrm{mm})$ & 79.19 & 22.93 & 6.24 & 84.10 & 25.10 & 7.25 \\
\hline & $\mathrm{TM}(\mathrm{g})$ & 260.50 & 210.40 & 16.91 & 311.60 & 304.80 & 20.98 \\
\hline & $\mathrm{JY}(\%)$ & 42.15 & 20.80 & 11.95 & 47.01 & 16.97 & 6.57 \\
\hline & Yield(kg.quadrant $\left.{ }^{-1}\right)$ & 17.15 & 20.85 & 34.35 & 18.72 & 21.99 & 40.07 \\
\hline
\end{tabular}

SW (southwest), NW (northwest), SE (southeast), NE (northeast), ED (equatorial diameter), TFM (total fruit mass), JY (juice yield), CV (coefficient of variation), ED (equatorial diameter), TM (total mass) and JY (juice yield).

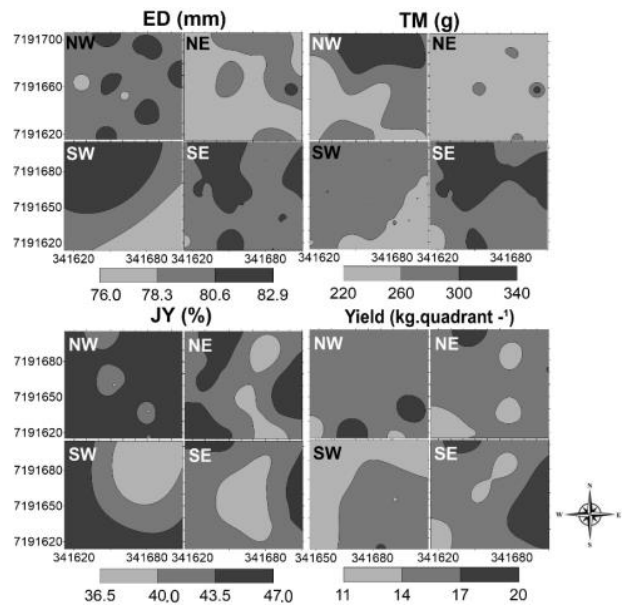

Fig 1. Maps of the spatial variability of the properties of oranges relative to their respective quadrants for 2011. (NW = northwest, $\mathrm{NE}=$ northeast, $\mathrm{SW}=$ southwest, $\mathrm{SE}=$ southeast $\mathrm{ED}=$ equatorial diameter, $\mathrm{TM}=$ total mass, $\mathrm{JY}=$ juice yield).

Table 2. Models and parameters of the semivariograms for the yield and physical properties of orange fruits in 2011 and 2012 located in Nova Laranjeiras, Paraná.

\begin{tabular}{|c|c|c|c|c|c|c|c|}
\hline & & 2011 & & & 2012 & & \\
\hline Quadrants & Properties & Model & $\begin{array}{l}\text { al } \\
(\mathrm{m})\end{array}$ & $\begin{array}{l}\text { ISD } \\
(\%)\end{array}$ & Model & $\begin{array}{l}\text { al } \\
(\mathrm{m})\end{array}$ & ISD $(\%)$ \\
\hline \multirow{4}{*}{ SW } & $\mathrm{ED}(\mathrm{mm})$ & Gau & 57.99 & 95.48 & Sph & 26.91 & 77.94 \\
\hline & $\mathrm{TM}(\mathrm{g})$ & $*$ & - & - & Gau & 36.30 & 86.96 \\
\hline & $\mathrm{JY}(\%)$ & Gau & 57.81 & 62.93 & Gau & 57.81 & 62.93 \\
\hline & $\begin{array}{l}\text { Yield } \\
\text { (kg.quadrant }^{-1} \text { ) }\end{array}$ & $*$ & - & - & Sph & 49.60 & 15.63 \\
\hline \multirow{4}{*}{ NW } & $\mathrm{ED}(\mathrm{mm})$ & Sph & 18.16 & 57.14 & Gau & 31.95 & 56.86 \\
\hline & $\mathrm{TM}(\mathrm{g})$ & Gau & 25.08 & 40.00 & Sph & 47.34 & 60.00 \\
\hline & JY (\%) & $*$ & - & - & Gau & 42.17 & 46.73 \\
\hline & $\begin{array}{l}\text { Yield } \\
\text { (kg.quadrant }^{-1} \text { ) }\end{array}$ & Sph & 26.48 & 27.42 & Gau & 39.34 & 56.36 \\
\hline \multirow{4}{*}{ SE } & $\mathrm{ED}(\mathrm{mm})$ & $*$ & - & - & Sph & 47.32 & 61.82 \\
\hline & $\mathrm{TM}(\mathrm{g})$ & Sph & 39.02 & 25.00 & Sph & 35.39 & 65.38 \\
\hline & $\mathrm{JY}(\%)$ & Exp & 63.84 & 20.51 & Gau & 7.04 & 54.89 \\
\hline & $\begin{array}{l}\text { Yield } \\
\text { (kg.quadrant }^{-1} \text { ) }\end{array}$ & Exp & 26.40 & 67.57 & Gau & 32.49 & 58.82 \\
\hline \multirow{4}{*}{$\mathrm{NE}$} & $\mathrm{ED}(\mathrm{mm})$ & Sph & 13.77 & 63.16 & Gau & 30.93 & 48.00 \\
\hline & $\mathrm{TM}(\mathrm{g})$ & Sph & 28.41 & 50.00 & Exp & 40.70 & 68.68 \\
\hline & JY $(\%)$ & Sph & 37.79 & 50.00 & Gau & 46.12 & 61.65 \\
\hline & $\begin{array}{l}\text { Yield } \\
\text { (kg.quadrant }^{-1} \text { ) }\end{array}$ & Sph & 17.88 & 47.06 & Gau & 44.47 & 17.24 \\
\hline
\end{tabular}

SW (southwest), NW (northwest), SE (southeast), NE (northeast), ED (equatorial diameter), TFM (total fruit mass), JY (juice yield), * maps interpolated by inverse distance did not present spatial dependence, Gau (Gaussian), Exp (exponential), Sph (spherical), al (reach), ISD (index of spatial dependence), ED (equatorial diameter), TM (total mass) and JY (juice yield). 


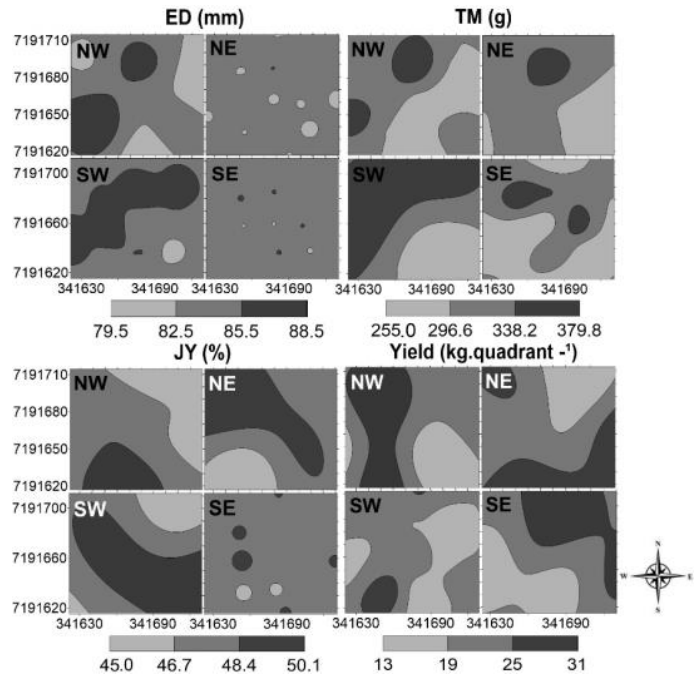

Fig 2. Maps of the spatial variability of the properties of oranges relative to their respective quadrants for 2012 . (NW $=$ northwest, $\mathrm{NE}=$ northeast, $\mathrm{SW}=$ southwest, $\mathrm{SE}=$ southeast $\mathrm{ED}=$ equatorial diameter, $\mathrm{TM}=$ total mass, $\mathrm{JY}=$ juice yield).

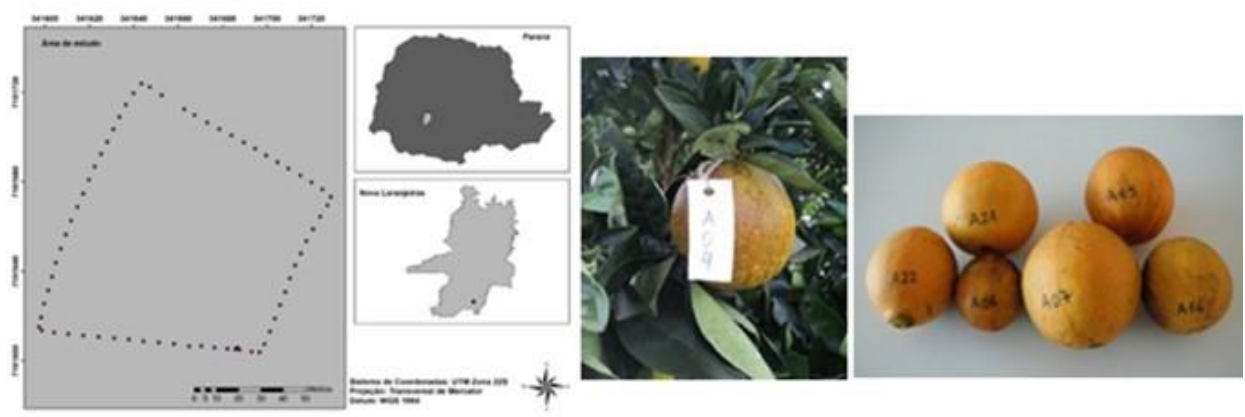

Fig 3. Location of the experimental area (a); identification of the tree fruits (b) and laboratory (c), respectively.

The orange trees (sample units), 30 metres from each other, were divided into the following quadrants: northwest (NW), northeast (NE), southwest (SW), southeast (SE). The collection of fruit coordinates occurred 30 days before harvest. The fruits were located by local coordinates within each quadrant of the trees (Figure $3 \mathrm{~b}$ and Figure $3 \mathrm{c}$ ), using a total station TOPCON GTP-7505, and after this procedure, the fruits were collected. For georeferencing the area and each sample of orange trees, we used the GPS receiver Trimble GeoExplorer 2005 XT, with submetre accuracy for post-corrected data.

\section{Yield estimation and physical analysis}

The yield was estimated by adapting the methodologies by Farias et al. (2003) and Triboni and Barbosa (2004), for which we counted orange fruits belonging to each quadrant of the sample trees. After harvesting, fruits were weighed, and thus the average yield value was obtained $\left(\mathrm{kg}\right.$. quadrant $\left.^{-1}\right)$ for each quadrant.

Physical analyses were performed at the Product Quality Control Laboratory, LACON, UNIOESTE campus of Cascavel, Parana. For each fruit, the following physical properties were quantified: equatorial diameter (ED), total mass (TM) and juice yield (JY) using analytical standards of the Institute Adolfo Lutz (IAL, 2008).

\section{Statistical and geostatistical analysis}

Initially, an exploratory analysis of data was performed to verify the position measurements, dispersion and shape. The normality of the data was verified using the Shapiro-Wilk test and Anderson-Darling at 5\% significance level, assuming normality of data when it was verified in at least one of the tests. The spatial analysis was performed to model the spatial variability of the variables studied in order to determine the degree of spatial dependence between samples through adjustments to semivariograms using theoretical models. The semivariograms were adjusted by theoretical models (spherical, exponential and Gaussian) using the following parameter estimation methods: ordinary least squares (OLS), weighted least squares and maximum likelihood.

In the analysis of the degree of spatial dependence, we used Cambardella et al.'s (1994) classification, considering the degree of spatial dependence (DSD) strong to semivariograms that have a nugget effect $\leq 25 \%$, moderate when it is between 25 and $75 \%$ and weak when DSD $\geq 75 \%$. The DSD is described in Equation 1. 
$\operatorname{DSD}=\frac{\mathrm{C}_{0}}{\mathrm{C}_{0}+\mathrm{C}_{1}} \times 100$

where: $\mathrm{C}_{0}$ is the nugget effect and $\mathrm{C}_{1}$ is the contribution. Cross-validation was used to evaluate the best model for the theoretical semivariogram. Surface maps were generated using data interpolation by kriging for the variables that presented spatial dependence and the inverse of the distance to the variables that did not present spatial dependence.

\section{Conclusion}

The PA techniques used were important tools to model the spatial variability of the physical properties and orange yield. The physical property values and orange yield vary according to the position of the fruit on the tree canopy, primarily evidenced in this study by the characteristics of juice yield (JY) and yield per quadrant. The spatial dependence was observed in all the physical characteristics studied as well as the yield, indicating the influence of spatial location of the fruit on the tree canopy, regardless of the quadrants.

\section{Acknowledgements}

The authors are grateful to the National Council for Scientific and Technological Development $(\mathrm{CNPq})$ and the Coordination for the Improvement of Higher Education Personnel (Capes) for financial support; and to Mr Luiz Konopatzki for allowing the study of the agricultural property for the experiment.

\section{References}

Azevêdo, CLL (2003) Sistema de Produção de Citros para o Nordeste: Colheita e Pós- colheita. Available online at: $<\mathrm{http} / / /$ sistemasdeproducao.cnptia.embrapa.br/FontesHTM L/Citros/CitrosNordeste/colheita.htm.>. Accessed 12 March 2012.

Bernardi ACC, Rabello LM, Inamasu RY, Grego CR, Andrade RG (2014) Variabilidade espacial de parâmetros físico-químicas do solo e biofísicos de superfície em cultivo do sorgo. R Bras Eng Agr Amb. 18: 623-630.

Cambardella CA, Moorman TB, Novak JM, Parkin TB, Karlen DL, Turco RF, Konopka AE (1994) Field-scale variability of soil properties in central Iowa soils. Soil Science S Am J. 58: 1501-1511.

Castro DBA, Maurício FN, Cristofani-Yaly M, Bastiniel M, Schinor EH, Verruma-Bernardi MR (2013) Sensory analysis of new varieties of citrus as a complementary strategy to the Brazilian citriculture. J Agr Sci. 5: 161-171.

Companhia de Entrepostos e Armazéns Gerais de São Paulo (CEAGESP) (2011) Normas de Classificação de Citros de Mesa. São Paulo, p 12. Available online at: <http://http://www.ceagesp.gov.br/wp-

content/uploads/2015/07/citros.pdf.>. Accessed 28 February 2017.

Cruz MCM, Ramos JD, Oliveira DL, Marques VB, Villar L (2010) Características físico-químicas da tangerina
'Ponkan' submetida ao raleio químico em relação à disposição na copa. Ciência e Agrotecnologia. 34: 37-42.

Detoni AM, Herzog NFM, Ohland T, Kotz T, Clemente E (2009) Influência do sol nas características físicas e químicas da tangerina 'Ponkan' cultivada no Oeste do Paraná. Ciência e Agrotec. 33: 624-628.

Duarte TF, Bron ILU, Ribeiro RV, Machado EC, Mazzafera P, Shimizu MM (2011) Efeito da carga pendente na qualidade de frutos de laranjeira 'Valência'. R. B. Fruticultura. 33: 823-829.

Empresa Brasileira de Pesquisa Agropecuária (EMBRAPA) (2013) Sistema Brasileiro de classificação de solos. EMBRAPA Solos. Brasília. p 353.

Farias PRS, Nociti LAS, Barbosa JC, Perecin D (2003) Agricultura de precisão: mapeamento de produtividade em pomares cítricos usando geoestatística. R B Fruticultura. 25: 235-241.

Instituto Adolfo Lutz (IAL) (2008) Normas Analíticas do Instituto Adolfo Lutz: Métodos químicos e físicos para análise de alimentos. Instituto Adolfo Lutz. São Paulo. p 819.

Koller OC (2006) Citricultura: 1. Laranja: Tecnologia de produção, pós-colheita, industrialização e comercialização. Cinco Continentes. Porto Alegre. p 396.

Lemos LMC, Siqueira DL, Salomão LCC, Cecon PR, LemosJP (2012) Características físico-químicas da laranjapera em função da posição na copa. R B Fruticultura. 34: 1091-1097.

Molin JP (2010) Agricultura de Precisão: O gerenciamento da variabilidade. Degaspari. p 83.

Molin JP, Rabello LM (2011) Estudos sobre a mensuração da condutividade elétrica do solo. Eng Agr. 31: 90-101.

Molin JP, Colaço AF, Carlos EF, Mattos Junior D (2012) Yield mapping, soil fertility and tree gaps in an orange orchard. R B Fruticultura. 34: 1256-1265.

Oliveira PCG, Farias PRS, Lima HV, Fernandes AR, Oliveira FA, Pita JD (2009) Variabilidade especial de propriedades químicas do solo e da produtividade de citros na Amazônia Oriental. R Bras Eng Agr Amb. 13: 708-715.

Santarosa E, Koller OC, Casamali B, Petry HB (2013) Produção e qualidade físico-química de frutos de laranjeiras 'Valência' em diferentes intensidade e frequências de poda. R B Fruticultura. 35: 790-798.

Siqueira DS, Marques JJ, Pereira GT (2010) The use of landforms to predict the variability of soil and orange attributes. Geoderma. 155: 55-66.

Triboni HR, Barbosa JC (2004) Estimativa do número de frutos por amostragem de parte da copa em laranjeiras. R B Fruticultura. 26: 454-458.

Zucoloto M, Lima JSS, Coelho RI, Silva AS, Passos RR (2011) Variabilidade espacial de atributos físicos e variáveis agronômicas de citros em uma parcela experimental em Jerônimo Monteiro (ES). R Eng Agricultura. 19: 28-35. 